\title{
Marten Use of Subnivean ACCess Points IN YELLOWSTONE
}

\author{
STUART SHERBURNE $\bullet$ JOHN BISSONETTE \\ UTAH COOPERATIVE FISH AND WILDLIFE RESEARCH UNIT \\ UTAH STATE UNIVERSITY $\bullet$ LOGAN
}

\section{$\checkmark \quad$ INTRODUCTION}

American marten (Martes americana) use primarily old growth coniferous habitat (Bateman 1986, Raine 1983, Soutiere 1979, Steventon and Major 1982). However, their use of habitat may vary by season (Steventon and Major 1982, Koehler and Hornocker 1977, Wynne and Sherburne 1984). In summer, marten use of non-forested areas to forage for fruits and berries has been documented (Soutiere 1979, Steventon and Major 1982). While there is some seasonal variation in habitat use, all authors agree that old growth is the core habitat required by marten. During winter, marten tend to remain in mature coniferous forests and will seldom cross open areas greater than $100 \mathrm{~m}$ wide (Steventon and Major 1982, Soutiere 1979). Winter appears to be the most critical period for marten survival (Zielinski et al. 1983, Buskirk 1984).

In winter, marten seem to require subnivean access for three major reasons: food, escape cover, and homeothermy. The use of subnivean access points has been well documented (Pullianen 1981, Buskirk 1984, Buskirk et al. 1989), but the mechanisms that determine the use of some access points and not others are not well understood. Certainly there is a relationship between the use of access points and coarse woody debris (CWD). Buskirk et al. (1989) found that $49 \%$ of marten resting sites and $63 \%$ of resting episodes were associated with CWD. CWD provides structure that breaks the snow surface, providing access to the subnivean zone where marten may escape low ambient temperatures, find prey or escape from predators. Buskirk (1989) has suggested that marten use subnivean access points to reach CWD that provides insulation from the cold. Marten in Wyoming (Buskirk et al. 1989) were found to use resting (access) sites associated with CWD when ambient temperatures were coldest; therefore, use of access points can decrease the metabolic demand for maintenance of body temperature. Studies of marten activity patterns, however, have shown that marten are most active at night during the winter (Zielinski 1981, Zeilinski et al. 1983, Lensink et al. 1955) when temperatures are coldest. This strategy is not energetically beneficial from a thermoregulatory standpoint and implies that other mechanisms may contribute to access point use. Microtines are the major food item in marten diets. Additionally, marten tend to hunt on a daily basis and their activity patterns in winter tend to be nocturnal. Zielinski et al. (1983) showed a correlation between marten activity and the activity of their principle prey in California. These aspects of their natural history suggest a relationship between the use of subnivean access points and prey densities. The primary goal of this study is to determine if this relationship occurs. 


\section{- GOALS AND OBJECTIVES}

The goal of this study was to identify the variables that influence subnivean access. Our primary objective was to examine the relationship between subnivean access and subnivean prey abundance (see methods). Specifically, we attempted to determine if a correlation existed between used access points and the abundance of subnivean prey. If there was a positive relationship between prey densities, CWD, and access points, then marten access point use should have been related to increased levels of CWD and high prey densities. This implies that either prey and or CWD are causal factors or covariates to causal factors for access point use by marten. We determined if these relationships existed by addressing the following hypotheses.

H1: Utilization of access points is positively correlated with subnivean prey abundance. If there is no prey at an access point, then we expect marten will not use that access point.

H2: Mean prey abundance at used access points will be higher than the mean prey abundance at non-used access points. If this is the case, it implies a positive relationship between prey and CWD and suggests a causal mechanism. Hypothesis 3 attempts to further elucidate the relationship.

H3: There will be a positive relationship between prey abundance and the $\%$ cover of CWD. We expect to find higher prey abundance at points with high levels of CWD.

\section{$\checkmark \quad$ STUdY AREA}

The Canyon-Norris region of Yellowstone National Park was chosen as the primary study area because it contained a variety of habitats suitable for marten and also provided a suitable road network for telemetry and accessibility to mârten habitat by foot. The major cover type of the area is lodgepole pine (Pinus contorta) with small to moderately sized spruce-fir inclusions. Varying degrees of fire intensity created a mosaic pattern of burned, partially burned and unburned cover types. Elevation ranges from approximately $2500 \mathrm{~m}$ to $3500 \mathrm{~m}$. Temperatures range from approximately $5^{\circ} \mathrm{C}$ to $-60^{\circ}$ $\mathrm{C}$ in winter and $25^{\circ} \mathrm{C}$ to $-5^{\circ} \mathrm{C}$ in summer. Normal snow accumulation during winter was about $2 \mathrm{~m}$, making this study area ideal for investigating subnivean access point use.

\section{$\checkmark \quad$ METHODS}

\section{HYPOTHESIS TESTS}

H1: To determine if a correlation existed between access point use and prey abundance, we first documented use of access points versus non-use, We then compared prey abundance at access points with prey abundance at non-used plots. Statistical analysis included a G-test, Student's t-test, and logistical regression.

H2: Random non-used access points were selected within the home ranges of marten as described in the sampling scheme. Small mammals were trapped on these plots and mean prey abundance for non-used points (see sampling scheme) compared to mean prey abundance at used access points. Data were based upon relative abundances of small mammals and seed bolus utilization. Results were compared as stated above. Analysis consisted of a G-test, Student's t-test and logistic regression.

H3: Prey abundance at access points and random plots were compared to CWD at the same points. CWD was measured as \% cover within a $10 \mathrm{~m}$ radius of the access or non-used point. Only CWD with a diameter of $7.6 \mathrm{~cm}$ or more was measured. Analysis included a G-test, Student's t-test, and logistic regression.

\section{ANALYSIS}

Multivariate analysis techniques were used to identify relations between the measured variables and access point utilization. Categorical interdependence methods, such as $\mathrm{G}$ square analysis and logistic regression techniques were used to determine if dependency relationships existed between access point use, prey density and CWD. The contingency table given below provides the basic data structure used for analysis (Table 1). 
Table 1. Data structure used for analysis to identify relations between measured varaibles and access point utilization.

MARTEN USE OF ACCESS POINTS

\begin{tabular}{lll}
\hline & YES & NO \\
& HIGH & $*$ \\
CWD LEVEL & MED & $*$ \\
& LOW & $*$ \\
PREY DENSITY & MED & $*$ \\
& LOW & $*$ \\
\hline
\end{tabular}

\section{$\checkmark \quad$ RESULTS}

Prey biomass was transformed using a squareroot function prior to analysis. Of the variables measured, CWD and prey biomass showed significant differences in mean values between used and unused access points. Mean prey biomass was $13.2 \mathrm{~g}$ and $9.0 \mathrm{~g}$ at used and unused points respectively ( $\underline{\mathrm{df}}=$ $142, \underline{t}=4.55, \mathrm{p}<0.0001)$. Mean percent ground cover of CWD was $24.7 \%$ and $18.5 \%$ respectively at used and unused access points $(\underline{\mathrm{df}}=102, \underline{\mathrm{t}}=2.39$, $\mathrm{p}=0.0166$ ). A multivariate logistic regression was performed using both CWD and prey biomass as explanatory variables. The Hosmer-Lemeshow test statistic of goodness of fit was $\mathbf{0 . 2 1 6}$ with $\underline{\mathrm{df}}=102$. For biomass the coefficient $(C)=0.0006$, the coef/se $=3.74$ and $\mathrm{p}=0.0003$. For CWD $(\mathrm{C})=0.02$, coef $/ \mathrm{se}=1.81, \mathrm{p}=0.0718$

\section{$\checkmark \quad$ ACCOMPLISHMENTS TO DATE}

All field work has been completed at this time and data analysis is nearing completion. We have prepared four manuscripts dealing with our research in Yellowstone and are in the process of submitting these for publication. A Master's thesis is also in preparation and should be completed early in 1992.

\section{- WORK REMAINING}

We are presently completing our data analysis by performing odds ratio tests on our prey and CWD dataset. We are also conducting additional experiments on marten habitat use and predator avoidance in Yellowstone and at Utah State University.

\section{$\checkmark \quad$ Literature Cited}

Bateman, M.C. 1986. Winter habitat use, food habits and home range size of the marten, Martes americana, in western Newfoundland. Can. Field-Nat. 100:58-62.

Buskirk, S.W. 1984. Seasonal use of resting sites by marten in south-central Alaska. J. Wildl. Manage. 48:950-953.

Buskirk, S.W., S.C. Forest, M.G. Raphael, and H.J. Harlow. 1989. Winter resting site ecology of marten in the central Rocky Mountains. J. Wildl. Manage. 53:191-196.

Koehler, G.M., and M.G. Hornocker. 1977. Fire effects on marten habitat in the Selway-Bitterroot Wilderness. J. Wildl. Manage. 41:500-505.

Lensink, C.A., R.O. Skoog, and J.L. Buckley. 1955. Food habits of marten in interior Alaska and their significance. J. Wildl. Manage. 19:364-368.

Pulliainen, E. 1981. Food and feeding habits of the pine marten in Finnish Forest Lapland in winter. Pages 580-598 In: J.A. Chapman and D. Pursley, eds. Worldwide Furbearer Conference Pro-ceedings. Baltimore, MD.

Raine, R.M. 1983. Winter habitat use and responses to snow cover of fisher and marten in southeastern Manitoba. Can. J. Zool. 65:25-34.

Soutiere, E.C. 1979. Effects of timber harvesting on marten in Maine. J. Wildl. Manage. 43:850860. 
Steventon, J.D., and J.T. Major. 1982. Marten use of a commercially clearcut forest. J. Wildl. Manage. 46:175-182.

Wynne, K.M., and J.A. Sherburne. 1984. Summer home range use by adult marten in northwestern Maine. Can. J. Zool. 62:941-93.

Zielinski, W.J. 1981. Food habits, activity patterns and ectoparasites of the pine marten at Sagenen Creek, California. MS thesis, Univ. California, Berkeley, CA. $121 \mathrm{pp}$.
Zielinski, W.J., W.D. Spencer, and R.H. Barrett. 1983. Relationship between food habits and activity patterns of pine martens. J. Mamm. 64:387-396. 